\title{
The role of trauma mechanism, fracture pattern and fixation technique on clinical outcomes and epiphyseal growth arrest in the surgical treatment of distal tibial epiphysiolysis
}

\author{
(D) Furkan Çağlayan Aslantaş, M.D.,' 1 Mustafa Yalın, M.D., ${ }^{2}$ () Mehmet Hakan İlter, M.D., ${ }^{3}$

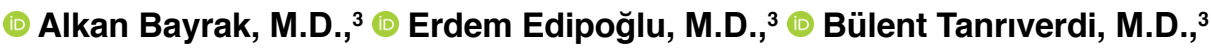 \\ (1) Altuğ Duramaz, M.D., ${ }^{3}$ ㄴ Mustafa Gökhan Bilgili, M.D. ${ }^{3}$
}

1'Department of Orthopedics and Traumatology, Ardahan State Hospital, Ardahan-Turkey

${ }^{2}$ Department of Orthopedics and Traumatology, Elazığ Training and Research Hospital, Elazı̆̆-Turkey

${ }^{3}$ Department of Orthopaedics and Traumatology, Bakırköy Dr. Sadi Konuk Training and Research Hospital, İstanbul-Turkey

\begin{abstract}
BACKGROUND: Distal tibial epiphyseal fractures damage to epiphyseal growth plate. Epiphyseal growth arrest (EGA), reflex sympathetic dystrophy and ankle joint stiffness may also occur after distal tibial epiphyseal injury. This study aims to evaluate the role of trauma mechanism, fracture pattern and fixation technique on clinical outcomes and EGA in the surgically treated distal tibial epiphyseal fractures.

METHODS: Twenty seven patients who underwent surgery for distal tibial epiphyseal fracture between the $20 \mathrm{II}$ and 2017 were evaluated retrospectively. The effects of trauma mechanism, fixation technique, preoperative duration, fracture patterns on the clinical results and EGA were examined. AOFAS (The American Orthopedic Foot and Ankle Score) and MOXFQ (The Manchester-Oxford Foot Questionaire) were used for clinical evaluation.

RESULTS: Twenty seven patients ( 17 male and 10 female) were included in this study. The most important complication of epiphyseal injury was the growth pause in eight patients. No statistically significant difference was observed concerning clinical scores and complications according to trauma mechanism, fixation techniques and fracture patterns $(p>0.05)$.
\end{abstract}

CONCLUSION: Regardless of the trauma mechanism, fracture pattern and the fixation material, an anatomical reduction should be obtained in distal tibial epiphyseal fractures to reduce complications and prevent the EGA.

Keywords: Distal tibial epiphyseal fractures; epiphyseal growth arrest; fixation technique; fracture pattern.

\section{INTRODUCTION}

Ankle fractures account for approximately $5 \%$ of all fractures in children and 15-20\% of all epiphyseal injuries and are the most common epiphyseal injury in the lower extremity. ${ }^{[1-4]}$ Ankle epiphyseal injuries are more common in males than females and tibia fractures are most common in eight to 15 years of age, and accompanying fibular fractures are most common between eight and 14 years. ${ }^{[5]}$ Epiphyseal growth arrest (EGA), osteoarthritis, reflex sympathetic dystrophy, and ankle joint stiffness may occur after distal tibial epiphyseal injury. The most important complication among these is the EGA. This complication is more frequent after Salter-Harris type 3 and 4 fractures and often causing limb length discrepancy and angular deformities of the ankle.

In the literature, the patients treated with open reduction and internal fixation for Salter\&Harris type 3 or 4 fracture have been shown to have an II-fold lower risk of developing a growth problem than the patients treated with closed

Cite this article as: Aslantaş FÇ, Yalın M, İlter MH, Bayrak A, Edipoğlu E, Tanrıverdi B, et al. The role of trauma mechanism, fracture pattern and fixation technique on clinical outcomes and epiphyseal growth arrest in the surgical treatment of distal tibial epiphysiolysis. Ulus Travma Acil Cerrahi Derg 2020;26:425-430.

Address for correspondence: Altuğ Duramaz, M.D.

Bakırköy Dr. Sadi Konuk Eğitim ve Araştırma Hastanesi, Ortopedi ve Travmataloji Kliniği, İstanbul, Turkey

Tel: +90 212 - 4147 I 71 E-mail: altug.duramaz@yahoo.com

Ulus Travma Acil Cerrahi Derg 2020;26(3):425-430 DOI: 10.14744/tjtes.2019.27354 Submitted: 10.04.2019 Accepted: 30.08 .2019 Online: 13.05.2020

Copyright 2020 Turkish Association of Trauma and Emergency Surgery 
reduction. ${ }^{[6]}$ Limb length discrepancy is associated with the age of the patient and is usually between 1 and $2 \mathrm{~cm} \cdot{ }^{[7]}$ The present study aims to evaluate the role of trauma mechanism, fracture pattern and fixation technique on clinical outcomes and epiphyseal growth arrest in the surgically treated distal tibial epiphyseal fractures. Our hypothesis is that K-wire fixation will be superior to clinical scores and EGA development compared to cannulated screw fixation.

\section{MATERIALS AND METHODS}

This study was compiled from a retrospective review of the medical records of 46 surgically treated patients for distal tibial epiphyseal injury between the years 20II-2017 after the approval of local ethics committee (Bakırköy Dr. Sadi Konuk Education and Research Hospital Ethics Committee, protocol code: 2017/43I, approval ID: 2017-18-3I). A distal tibial epiphyseal injury requiring surgery, displacements greater than 2 $\mathrm{mm}$, at least I-year follow-up, and no accompanying injuries were the inclusion criteria. Open fractures, inadequate followup duration, and conservative treatment were excluded from this study. Twenty-seven patients ( 17 male and 10 female) who met the inclusion criteria were included in this study. The mean age was 11.9 years (between 5 and 17 years old). The effects of trauma mechanism, fixation technique, preoperative duration, fracture types (classification of Salter-Harris and Dias\&Tachdjian) on the clinical results and EGA were examined. All patients were evaluated clinically and radiologically at postoperative $2^{\text {nd }}$ week, $6^{\text {th }}$ week, $3^{\text {rd }}$ month and $6^{\text {th }}$ month and then evaluated annually. AOFAS (The American Orthopedic Foot and Ankle Score) and MOXFQ (The Manchester-Oxford Foot Questionaire) were used for clinical evaluation. Radiological results, including EGA and fracture union, were evaluated by an independent senior orthopedic surgeon.

\section{Surgical Technique and Postoperative Care}

All patients infused $30 \mathrm{mg} / \mathrm{kg}$ intravenous cefazoline sodium 30 min before surgery. All patients were operated under general anesthesia in the supine position. The closed reduction under fluoroscopic guidance and minimally invasive or percutaneous fixation which parallel to the physeal line was performed. K-wire between $1.8 \mathrm{~mm}$ and $2.5 \mathrm{~mm}$ was used in I I patients, and HCCS (headless conical compression screw) with $2.5 \mathrm{~mm}$ diameter was used in 16 patients. The patients were followed for two weeks postoperatively with a below knee cast. Then, passive joint motion exercises were started by removing the cast. Patients were allowed to full weight bearing after radiographic fracture healing was demonstrated.

\section{Statistical Analysis}

Descriptive statistics (average, standard deviation, minimum, median, maximum) were used to define continuous variables. The relationship between more than two continuous variables, such as fracture classifications which were not suitable for an independent and normal distribution was examined by the Kruskal Wallis test. The relationship between two continuous variables, such as fibular fracture and trauma mechanism, which were not suitable for normal and normal distribution was investigated with the Mann-Whitney $U$ test. Chi-Square (or Fisher Exact test where appropriate) was used to examine the relationship between categorical variables, such as EGA and fixation technique. Spearman's rho correlation analysis was performed for the correlation of two continuous variables which do not conform to a normal distribution. The statistical significance level was determined as $p<0.05$. The analyses were performed using the MedCalc Statistical Software version 12.7.7 (MedCalc Software bvba, Ostend, Belgium; http://www.medcalc.org; 20I3).

\section{RESULTS}

The demographic characteristics of the patients are presented in Table I. The duration of operation of the patients

Table I. Descriptive characteristics of the patients

\begin{tabular}{lcc}
\hline & Mean \pm SD & Median (Min-Max) \\
\hline Age (year) & $11.9 \pm 3.2$ & $13(5-17)$ \\
Time to surgery & $4.3 \pm 2.03$ & $4(1-8)$ \\
AOFAS score & $86.04 \pm 9.8$ & $85(65-100)$ \\
MOXFQ Walking-Standing & $0.23 \pm 0.1$ & $0.21(0.03-0.6)$ \\
MOXFQ Social interaction & $0.16 \pm 0.1$ & $0.18(0-0.4)$ \\
MOXFQ Pain & $0.18 \pm 0.1$ & $0.15(0-0.36)$ \\
\hline
\end{tabular}

n

$\%$

Gender

$\begin{array}{lll}\text { Male } & 17 & 63 \\ \text { Female } & 10 & 37\end{array}$

Trauma mechanism

$\begin{array}{lcc}\text { High energy } & 8 & 29.6 \\ \text { Low energy } & 19 & 70.4\end{array}$

Fixation method

$\begin{array}{lll}\text { K wire } & \text { II } & 40.7 \\ \text { Cannulated screw } & 16 & 59.3\end{array}$

Epiphysial growth arrest

$\begin{array}{lcc}\text { No } & 19 & 70.4 \\ \text { Yes } & 8 & 29.6\end{array}$

Accompanying fibula fracture

$\begin{array}{lll}\text { No } & 17 & 63 \\ \text { Yes } & 10 & 37\end{array}$

Salter\&Harris classification

2

3

8

29.6

14

51.9

4

5

18.5

AOFAS: The American Orthopedic Foot and Ankle Score; MOXFQ: The Manchester-Oxford Foot Questionaire; SD: Standard deviation; Min: Minimum; Max: Maximum. 
Table 2. Functional evaluation and development of epiphyseal growth arrest according to fracture classification

\begin{tabular}{|c|c|c|c|c|}
\hline \multirow[t]{2}{*}{ Salter\&Harris classification } & 2 & 3 & 4 & \multirow[t]{2}{*}{$\mathbf{p}$} \\
\hline & $\begin{array}{c}\text { Mean } \pm \text { SD } \\
\text { Median (Min-Max) }\end{array}$ & $\begin{array}{c}\text { Mean } \pm \text { SD } \\
\text { Median (Min-Max) }\end{array}$ & $\begin{array}{c}\text { Mean } \pm \text { SD } \\
\text { Median (Min-Max) }\end{array}$ & \\
\hline \multirow[t]{2}{*}{ AOFAS } & $87.5 \pm 10.8$ & $84.7 \pm 10.5$ & $87.4 \pm 6.6$ & $0.808^{*}$ \\
\hline & 87 (67-98) & $84.5(65-100)$ & $87(80-97)$ & \\
\hline \multirow[t]{2}{*}{ MOXFQ Walking-Standing } & $0.25 \pm 0.17$ & $0.23 \pm 0.15$ & $0.23 \pm 0.1$ & $0.935^{*}$ \\
\hline & $0.23(0.03-0.6)$ & $0.23(0.07-0.6)$ & $0.17(0.14-0.37)$ & \\
\hline \multirow[t]{2}{*}{ MOXFQ Social interaction } & $0.14 \pm 0.14$ & $0.15 \pm 0.13$ & $0.23 \pm 0.14$ & $0.489^{*}$ \\
\hline & $0.16(0-0.31)$ & $0.15(0-0.37)$ & $0.25(0-0.4)$ & \\
\hline \multirow[t]{3}{*}{ MOXFQ Pain } & $0.16 \pm 0.12$ & $0.16 \pm 0.08$ & $0.27 \pm 0.07$ & $0.075^{*}$ \\
\hline & $0.12(0.05-0.35)$ & $0.15(0-0.3)$ & $0.3(0.2-0.36)$ & \\
\hline & n (\%) & n (\%) & n (\%) & $\mathbf{p}$ \\
\hline Epiphyseal growth arrest & $3(37.5)$ & $3(37.5)$ & $2(25.0)$ & $0.621^{* *+}$ \\
\hline \multirow[t]{2}{*}{ Dias\&Tachdijan classification } & PEE & SER & SI & $\mathbf{p}$ \\
\hline & $\begin{array}{c}\text { Mean } \pm S D \\
\text { Median (Min-Max) }\end{array}$ & $\begin{array}{c}\text { Mean } \pm \text { SD } \\
\text { Median (Min-Max) }\end{array}$ & $\begin{array}{c}\text { Mean } \pm \text { SD } \\
\text { Median (Min-Max) }\end{array}$ & \\
\hline \multirow[t]{2}{*}{ AOFAS } & $86.1 \pm 5.9$ & $89 \pm 11.9$ & $86.4 \pm 9.9$ & $0.588^{*}$ \\
\hline & $84(79-98)$ & $90(67-100)$ & $85(65-100)$ & \\
\hline \multirow[t]{2}{*}{ MOXFQ Walking-Standing } & $0.3 \pm 0.1$ & $0.2 \pm 0.2$ & $0.2 \pm 0.1$ & $0.109^{*}$ \\
\hline & $0.3(0.17-0.32)$ & $0.1(0.03-0.6)$ & $0.2(0.1-0.4)$ & \\
\hline \multirow[t]{2}{*}{ MOXFQ Social interaction } & $0.2 \pm 0.1$ & $0.1 \pm 0.1$ & $0.2 \pm 0.1$ & $0.097^{*}$ \\
\hline & $0.2(0-0.2)$ & $0(0-0.2)$ & $0.2(0-0.4)$ & \\
\hline \multirow[t]{3}{*}{ MOXFQ Pain } & $0.2 \pm 0.1$ & $0.2 \pm 0.1$ & $0.2 \pm 0.1$ & $0.935^{*}$ \\
\hline & $0.2(0.05-0.3)$ & $0.1(0.05-0.3)$ & $0.1(0-0.4)$ & \\
\hline & n (\%) & n (\%) & n (\%) & $\mathbf{p}$ \\
\hline Epiphyseal growth arrest & $3(37.5)$ & $3(37.5)$ & $2(25.0)$ & $0.393^{* *}$ \\
\hline
\end{tabular}

"Kruskal Wallis p, "Fisher's Exact p. AOFAS: The American Orthopedic Foot and Ankle Score; MOXFQ: The Manchester-Oxford Foot Questionaire; PEE: Pronationeversion-external rotation; SER: Supination-external rotation; SI: Supination-inversion; SD: Standard deviation; Min: Minimum; Max: Maximum.

differed due to various reasons, such as additional medical conditions and edema and blister formation after trauma. Dias \& Tachdjian and Salter Harris metods were used as fracture classification. There was no significant difference in AOFAS score, MOXFOQ score and EGA between subtypes of both fracture classification (Table 2). The most important complication of epiphyseal injury was the growth pause in eight patients. No statistically significant difference was observed concerning clinical scores and complications according to trauma mechanism (high-energy injury, such as traffic accident and falling from a height, low-energy injury, such as simple fall and buckling), fixation techniques (K-wire and HCCS) and fracture patterns $(p>0.05)$ (Table 3$)$.

\section{DISCUSSION}

The most important finding of the present study is that dif- ferent fixation techniques do not affect clinical scores and the development of EGA. Tibia distal epiphyseal injuries are the most common type of fracture in all epiphyseal injuries. ${ }^{[8]}$ Epiphyseal injuries are more frequent than diaphyseal fractures. ${ }^{[9]}$ Tibia distal epiphyseal injuries may lead to complications, such as damage to the epiphyseal growth due to the presence of the growth plate. The tibial epiphysial injury is often associated with fibula fractures. Cai et al. ${ }^{[10]}$ reported that the presence of concomitant fibula fracture increased EGA risk for Salter-Harris type 3 and type 4. Contrary to this study, it was determined that the presence of fibula injury did not cause a significant effect on the AOFAS and MOXFQ scores or on the risk of EGA in our study. This finding can be explained by anatomic reduction and percutaneous fixation that was performed for all patients with fibula fractures. 
Table 3. Comparison of postoperative $\left.\right|^{\text {st }}$ year functional outcomes and epiphyseal growth arrest according to fixation technique. trauma mechanism and presence of fibula fracture

\begin{tabular}{|c|c|c|c|}
\hline \multirow[t]{2}{*}{ Fixation technique } & \multirow{2}{*}{$\frac{\text { K wire }}{\text { Mean } \pm S D}$} & \multirow{2}{*}{$\begin{array}{c}\frac{\text { Cannulated screw }}{\text { Mean } \pm S D} \\
\text { Median (Min-Max) }\end{array}$} & \multirow[t]{2}{*}{$\mathbf{p}$} \\
\hline & & & \\
\hline \multirow[t]{2}{*}{ AOFAS } & $84.4 \pm I 1.4$ & $87.2 \pm 8.7$ & $0.512^{*}$ \\
\hline & $84(65-100)$ & $87.5(67-100)$ & \\
\hline \multirow[t]{2}{*}{ MOXFQ Walking-Standing } & $0.25 \pm 0.17$ & $0.23 \pm 0.13$ & $0.753^{*}$ \\
\hline & $0.25(0.03-0.6)$ & $0.21(0.07-0.6)$ & \\
\hline \multirow[t]{2}{*}{ MOXFQ Social interaction } & $0.17 \pm 0.14$ & $0.16 \pm 0.13$ & $0.716^{*}$ \\
\hline & $0.25(0-0.37)$ & $0.18(0-0.4)$ & \\
\hline \multirow[t]{3}{*}{ MOXFQ Pain } & $0.17 \pm 0.09$ & $0.19 \pm 0.11$ & $0.577^{*}$ \\
\hline & $0.15(0.05-0.3)$ & $0.2(0-0.36)$ & \\
\hline & n (\%) & n (\%) & $\mathbf{p}$ \\
\hline Epiphyseal growth arrest & $2(25.0)$ & $6(75.0)$ & $0.405^{* *}$ \\
\hline \multirow[t]{2}{*}{ Fibula fracture } & No & Yes & $\mathbf{p}$ \\
\hline & $\begin{array}{c}\text { Mean } \pm \text { SD } \\
\text { Median (Min-Max) }\end{array}$ & $\begin{array}{c}\text { Mean } \pm \text { SD } \\
\text { Median (Min-Max) }\end{array}$ & \\
\hline \multirow[t]{2}{*}{ AOFAS } & $85.8 \pm 9.9$ & $86.4 \pm 10.06$ & $1.00^{*}$ \\
\hline & $85(65-100)$ & $85(68-100)$ & \\
\hline \multirow[t]{2}{*}{ MOXFQ Walking-Standing } & $0.24 \pm 0.1$ & $0.22 \pm 0.16$ & $0.505^{*}$ \\
\hline & $0.21(0.07-0.6)$ & $0.23(0.03-0.6)$ & \\
\hline \multirow[t]{2}{*}{ MOXFQ Social interaction } & $0.17 \pm 0.13$ & $0.16 \pm 0.15$ & $0.863^{*}$ \\
\hline & $0.18(0-0.4)$ & $0.18(0-0.37)$ & \\
\hline \multirow[t]{3}{*}{ MOXFQ Pain } & $0.18 \pm 0.09$ & $0.18 \pm 0.1$ & $0.980^{*}$ \\
\hline & $0.2(0-0.36)$ & $0.15(0.05-0.35)$ & \\
\hline & n (\%) & n (\%) & $\mathbf{p}$ \\
\hline Epiphyseal growth arrest & $3(37.5)$ & $5(62.5)$ & $0.102^{* *}$ \\
\hline \multirow[t]{2}{*}{ Trauma mechanism } & High energy & Low energy & $\mathbf{p}$ \\
\hline & $\begin{array}{c}\text { Mean } \pm S D \\
\text { Median (Min-Max) }\end{array}$ & $\begin{array}{c}\text { Mean } \pm S D \\
\text { Median (Min-Max) }\end{array}$ & \\
\hline \multirow[t]{2}{*}{ AOFAS } & $82.4 \pm 11.9$ & $87.6 \pm 8.6$ & $0.238^{*}$ \\
\hline & $82.5(65-98)$ & $87(67-100)$ & \\
\hline \multirow[t]{2}{*}{ MOXFQ Walking-Standing } & $0.29 \pm 0.16$ & $0.21 \pm 0.13$ & $0.132^{*}$ \\
\hline & $0.28(0.07-0.6)$ & $0.17(0.03-0.6)$ & \\
\hline \multirow[t]{2}{*}{ MOXFQ Social interaction } & $0.24 \pm 0.12$ & $0.13 \pm 0.13$ & $0.058^{*}$ \\
\hline & $0.25(0-0.37)$ & $0.12(0-0.4)$ & \\
\hline \multirow[t]{3}{*}{ MOXFQ Pain } & $0.23 \pm 0.09$ & $0.16 \pm 0.09$ & $0.095^{*}$ \\
\hline & $0.25(0.05-0.35)$ & $0.15(0-0.36)$ & \\
\hline & n (\%) & n (\%) & $\mathbf{p}$ \\
\hline Epiphyseal growth arrest & $3(37.5)$ & $5(62.5)$ & $0.658^{* *}$ \\
\hline
\end{tabular}


Some authors have suggested that the arrest of growth arise from epiphyseal trauma at the time of injury. ${ }^{\left[{ }^{I I}\right]}$ It has been reported in the literature that growth plate problems are more frequent after Salter-Harris type 3-4 injuries. ${ }^{[12,13]}$ The most important complication of epiphyseal injury, EGA, was $29.6 \%$ (eight patients) in the present study. Although SalterHarris type 3 and 4 fractures were moderately worse than type 2 fractures in accordance with the literature, no statistically significant difference was observed concerning EGA in the present study. Dias and Tachdjian ${ }^{[14]}$ noted that the most common type of injury was the supination inversion type injury. On the other hand, Rohmiller et al. ${ }^{[15]}$ reported that there was a relationship between the injury mechanism and EGA and that they observed 35\% EGA, especially after supination-external rotation injury. In the present study, the most common injury mechanism was supination-inversion and the rate of EGA in patients with supination-external rotation injury was $42 \%$. No difference was observed between the Dias \& Tachdjian fracture types concerning EGA rate.

Taşkıran et al. ${ }^{[16]}$ performed the first study that the AOFAS scoring system was used as a quantitative data in children with tibial distal growth plate fractures. The AOFAS score for their study was 86.6. In another study, Çiçekli et al. ${ }^{[1]}$ used the AOFAS score and recorded an average AOFAS score of 96. In the present study, the mean AOFAS score was 86.04 , in accordance with the literature. To our knowledge, this is the first study in the literature that has used the MOXFQ score in children with tibial distal growth plate fractures. In the MOXFQ scoring system, the results range from 0 to I and functional results are improved when approaching 0 . The three parameters of this scoring system, walking/standing, pain, and social interaction, had mean values of $0.23,0.18$, 0.16 , respectively in the present study. Although the pain of the operated extremity increased with movement and walking, the functional results were good. Also, no statistically significant difference was found between mean AOFAS and mean MOXFQ scores when the patients were grouped according to Dias \& Tachdjian classification and Salter-Harris classification. In the present study, there were no statistically significant differences in the comparison of AOFAS and MOXFQ scores in eight patients diagnosed with epiphysiolysis after high-energy trauma and 19 patients diagnosed with the low-energy injury. Leary et al. ${ }^{[18]}$ reported that high-energy trauma increased the risk of EGA compared to low-energy trauma or sports injuries. In the present study, there was no increase in the risk of EGA in high-energy trauma patients with no difference in clinical outcomes.

Özkul et al. ${ }^{[19]}$ also reported that high-energy trauma did not increase the risk of EGA. We think that anatomic reduction has a positive effect on functional outcome even in cases of high energy injury. It was determined that preoperative hospitalization time did not affect the EGA risk. Also, no significant relationship was found between preoperative hospitalization time and AOFAS and MOXFQ scores.
Different types of implants have been used for fixation of epiphyseal fractures. In previous studies, $\mathrm{K}$ wires, tension band, metallic screws and bioabsorbable screws were used for fixation. ${ }^{[20-23]}$ A biomechanical study showed that metallic screw fixation in the distal tibia significantly changed the intraarticular pressure in the ankle joint. ${ }^{[24]}$ Cottalorda suggested an epiphyseal lag screw in the spongiform bone to provide anatomic reduction and better compression of the fracture line, stating that the reduction and compression were better with screws than with $\mathrm{K}$ wires. ${ }^{[25]}$ Çicekli et al. ${ }^{[17]}$ compared cannulated screws with headless cannulated screws in the treatment of distal tibial epiphyseal fractures but found no difference in clinical healing outcomes or complication rates. In the series where plain thin K-wires were used, there were less growth plate problems compared to the series made with other fixation materials. ${ }^{[16]}$ In our patients, $\mathrm{K}$ wires or cannulated screws were used as the fixation material after anatomic reduction under the fluoroscopic guidance. In our study, a cannulated screw was preferred for anatomic fixation and compression of the fracture line in Salter-Harris Type 3 fractures. There was no statistically significant relationship between the type of fixation and clinical outcome and complication rate. This statistical determination refuted our hypothesis, which can be explained with that the patients are operated on in a short time and soft tissue problems are reduced. Thus, the fractures can be easily reduced with closed anatomic reduction maneuver. Also, K-wire is theoretically less damaging to the physeal region due to its smaller diameter and its application without drilling. This has a positive effect on clinical scores and may reduce the risk of EGA. In our study, it was thought that there was no significant difference in clinical scores and EGA due to the close diameters of K-wire and HCCS used as fixation material. Small the number of patients, retrospective design and short follow-up time are the limitations of the present study.

In conclusion, EGA and clinical scores did not differ significantly concerning trauma mechanism, fracture pattern and fixation material in our study. Therefore, regardless of the trauma mechanism, fracture pattern, and fixation material, anatomic reduction is critical in distal tibial epiphyseal fractures to reduce complications and prevent EGA. Different fixation techniques may not affect clinical scores and the development of EGA.

Ethics Committee Approval: Bakırköy Dr. Sadi Konuk Education and Research Hospital Ethics Committee, protocol code: 2017/43I, approval ID: 2017-I8-3I.

Peer-review: Internally peer-reviewed.

Authorship Contributions: Concept: F.Ç.A., M.G.B.; Design: F.Ç.A., M.G.B; Supervision: M.Y., M.H.I.; Fundings: M.Y, B.T., M.H.I.; Materials: F.Ç.A, B.T, E.E.; Data: F.Ç.A, M.H.I.; Analysis: A.B., A.D.; Literature search: F.Ç.A, A.B., A.D.; Writing: F.Ç.A, A.D.; Critical revision: A.D., M.G.B.

Conflict of Interest: None declared.

Financial Disclosure: The authors declared that this study has received no financial support. 


\section{REFERENCES}

1. Landin LA, Danielsson LG. Children's ankle fractures. Classification and epidemiology. Acta Orthop Scand 1983;54:634-40. [CrossRef]

2. Peterson HA, Madhok R, Benson JT, Ilstrup DM, Melton LJ 3rd. Physeal fractures: Part 1. Epidemiology in Olmsted County, Minnesota, 1979-1988. J Pediatr Orthop 1994;14:423-30. [CrossRef]

3. Peterson CA, Peterson HA. Analysis of the incidence of injuries to the epiphyseal growth plate. J Trauma 1972;12:275-81. [CrossRef]

4. Mizuta T, Benson WM, Foster BK, Paterson DC, Morris LL. Statistical analysis of the incidence of physeal injuries. J Pediatr Orthop 1987;7:518-23. [CrossRef]

5. Spiegel PG, Cooperman DR, Laros GS. Epiphyseal fractures of the distal ends of the tibia and fibula. A retrospective study of two hundred and thirty-seven cases in children. J Bone Joint Surg Am 1978;60:1046-50.

6. Kling TF Jr, Bright RW, Hensinger RN. Distal tibial physeal fractures in children that may require open reduction. J Bone Joint Surg Am 1984;66:647-57. [CrossRef]

7. Caterini R, Farsetti P, Ippolito E. Long-term followup of physeal injury to the ankle. Foot Ankle 1991;11:372-83. [CrossRef]

8. Hynes D, O'Brien T. Growth disturbance lines after injury of the distal tibial physis. Their significance in prognosis. J Bone Joint Surg Br 1988;70:231-3. [CrossRef]

9. Oeppen RS, Connolly SA, Bencardino JT, Jaramillo D. Acute injury of the articular cartilage and subchondral bone: a common but unrecognized lesion in the immature knee. AJR Am J Roentgenol 2004;182:111-7.

10. Cai H, Wang Z, Cai H. Surgical indications for distal tibial epiphyseal fractures in children. Orthopedics 2015;38:e189-95. [CrossRef]

11. Dugan G, Herndon WA, McGuire R. Distal tibial physeal injuries in children: a different treatment concept. J Orthop Trauma 1987;1:63-7.

12. Bellido PC, Wadhwani J. Retrospective observational study comparing treatment options in salter and harris type III epiphyseal fractures. Int J Orth Scie 2017;3:188-90. [CrossRef]

13. de Sanctis N, Della Corte S, Pempinello C. Distal tibial and fibular epiphyseal fractures in children: prognostic criteria and long-term results in 158 patients. J Pediatr Orthop B 2000;9:40-4. [CrossRef]
14. Dias LS, Tachdjian MO. Physeal injuries of the ankle in children: classification. Clin Orthop Relat Res 1978;:230-3. [CrossRef]

15. Rohmiller MT, Gaynor TP, Pawelek J, Mubarak SJ. Salter-Harris I and II fractures of the distal tibia: does mechanism of injury relate to premature physeal closure?. J Pediatr Orthop 2006;26:322-8. [CrossRef]

16. Taşkıran MC, Turgut A, Kalenderer $\mathrm{O}$, Ağuş H. Clinical and radiological results in distal tibial physeal injuries. [Article in Turkish]. Ulus Travma Acil Cerrahi Derg 2012;18:495-500. [CrossRef]

17. Çiçekli Ö, Özdemir G, Uysal M, Biçici V, Bingöl İ. Percutaneous cannulated screw fixation for pediatric epiphyseal ankle fractures. Springerplus 2016;5:1925. [CrossRef]

18. Leary JT, Handling M, Talerico M, Yong L, Bowe JA. Physeal fractures of the distal tibia: predictive factors of premature physeal closure and growth arrest. J Pediatr Orthop 2009;29:356-61. [CrossRef]

19. Özkul B, Saygılı MS, Çetinkaya E, Arslanoğlu F, Bayhan IA, Demir B, et al. Angular deformity development after the distal tibial physeal fractures. Acta Orthop Belg 2016;82:814-20.

20. Wuerz TH, Gurd DP. Pediatric physeal ankle fracture. J Am Acad Orthop Surg 2013;21:234-44. [CrossRef]

21. Podeszwa DA, Wilson PL, Holland AR, Copley LA. Comparison of bioabsorbable versus metallic implant fixation for physeal and epiphyseal fractures of the distal tibia.J Pediatr Orthop 2008;28:859-63. [CrossRef]

22. Castellani C, Riedl G, Eberl R, Grechenig S, Weinberg AM. Transitional fractures of the distal tibia: a minimal access approach for osteosynthesis. J Trauma 2009;67:1371-5. [CrossRef]

23. Sankar B, Lee NY, Henman PD. Periosteal tension band fixation of a pronation external rotation type fracture of the ankle in a child. Orthopedics 2013;36:444-8. [CrossRef]

24. Charlton M, Costello R, Mooney JF 3rd, Podeszwa DA. Ankle joint biomechanics following transepiphyseal screw fixation of the distal tibia. J Pediatr Orthop 2005;25:635-40. [CrossRef]

25. Cottalorda J, Béranger V, Louahem D, Camilleri JP, Launay F, Diméglio A, et al. Salter-Harris Type III and IV medial malleolar fractures: growth arrest: is it a fate? A retrospective study of 48 cases with open reduction. J Pediatr Orthop 2008;28:652-5. [CrossRef]

\section{ORİJINAL ÇALIŞMA - ÖZET}

\section{Distal tibial epifizyolizin cerrahi tedavisinde travma mekanizması, kırık paterni ve fiksasyon tekniğinin klinik sonuçlar ve epifiz büyümesinin durması üzerine etkisi \\ Dr. Furkan Çağlayan Aslantaş, ${ }^{1}$ Dr. Mustafa Yalın, ${ }^{2}$ Dr. Mehmet Hakan İlter, ${ }^{3}$ Dr. Alkan Bayrak, ${ }^{3}$ Dr. Erdem Edipoğlu, ${ }^{3}$ Dr. Bülent Tanrıverdi, ${ }^{3}$ Dr. Altuğ Duramaz, ${ }^{3}$ Dr. Mustafa Gökhan Bilgili ${ }^{3}$}

${ }^{1}$ Ardahan Devlet Hastanesi, Ortopedi ve Travmataloji Kliniği, Ardahan

${ }^{2}$ Elazığ Eğitim ve Araştırma Hastanesi, Ortopedi ve Travmataloji Kliniği, Elazığ

${ }^{3}$ Bakırköy Dr. Sadi Konuk Eğitim ve Araştırma Hastanesi, Ortopedi ve Travmataloji Kliniği, İstanbul

AMAÇ: Distal tibial epifiz kırıkları, epifiz büyüme plağına zarar verir. Distal tibial epifiz yaralanmasından sonra epifiz büyümesi durması (EBD), osteoartrit, refleks sempatik distrofi ve ayak bileği eklemi sertliği de görülebilir. Bu çalışmanın amacı, cerrahi olarak tedavi edilen distal tibial epifiz kırıklarında travma mekanizması, kırık paterni ve fiksasyon tekniğinin klinik sonuçlar ve EBD üzerindeki etkisini değerlendirmektir.

GEREÇ VE YÖNTEM: 20 I I-2017 yılları arasında distal tibial epifiz kırı̆ı̆ı nedeniyle opere edilen 27 hasta geriye dönük olarak değerlendirildi. Travma mekanizması, fiksasyon tekniği, ameliyat öncesi süre, kırık tipinin klinik sonuçlar ve EBD üzerine etkileri incelendi. Klinik sonuçlar AOFAS (Amerikan Ortopedik Ayak ve Ayak Bileği Skoru) ve MOXFQ (Manchester-Oxford Ayak Anketi) skorları ile değerlendirildi.

BULGULAR: Çalışmaya alınan 27 hastanın I7'si erkek, 10'u kadındı. Hastaların yaş ortalaması II.9 idi (dağıım 5-I7 yaş). Epifizyal hasarın en önemli komplikasyonu sekiz hastada büyüme duraklamasıydı. Travma mekanizması, fiksasyon teknikleri ve kırık paternine göre klinik skorlar ve komplikasyonlar açısından istatistiksel olarak anlamlı bir fark gözlenmedi ( $p>0.05)$.

TARTIŞMA: Travma mekanizması, kırık paterni ve fiksasyon materyali ne olursa olsun, distal tibial epifiz kırıklarında komplikasyonları azaltmak ve EBD’yi önlemek için anatomik bir redüksiyon elde edilmelidir.

Anahtar sözcükler: Distal tibial epifiz kırıkları; epifiz büyümesi duraksaması; fiksasyon tekniği; kırık paterni.

Ulus Travma Acil Cerrahi Derg 2020;26(3):425-430 doi: 10.14744/tjtes.2019.27354 